\title{
Synthesis of Binaphthyl-Based Push-Pull Chromophores with Supramolecularly Polarizable Acceptor Ends
}

\author{
Carmine Coluccini, ${ }^{1,2}$ Giancarlo Terraneo, ${ }^{3}$ and Dario Pasini ${ }^{1,4}$ \\ ${ }^{1}$ Department of Chemistry, University of Pavia, Viale Taramelli 10, 27100 Pavia, Italy \\ ${ }^{2}$ IMDEA Materials, C/ Eric Kandel 2, Tecnogetafe, Getafe, 28906 Madrid, Spain \\ ${ }^{3}$ Dipartimento di Chimica, Materiali ed Ingegneria Chimica “G. Natta”, Politecnico di Milano, Via L. Mancinelli 7, 20131 Milano, Italy \\ ${ }^{4}$ INSTM Research Unit, University of Pavia, Italy
}

Correspondence should be addressed to Carmine Coluccini; carmine.coluccini@imdea.org and Dario Pasini; dario.pasini@unipv.it

Received 11 December 2014; Revised 19 February 2015; Accepted 23 February 2015

Academic Editor: Narcis Avarvari

Copyright (C) 2015 Carmine Coluccini et al. This is an open access article distributed under the Creative Commons Attribution License, which permits unrestricted use, distribution, and reproduction in any medium, provided the original work is properly cited.

We report on the design and synthesis of new enantiopure binaphthyl derivatives in which electron-donating and electronwithdrawing substituents are placed in direct conjugation, to create push-pull dyes potentially active for NLO applications. The dyes, unprecedentedly, extend their $\pi$-bridge from the $3,3^{\prime}$ positions of the binaphthyl units and incorporate as acceptors 1,3-dicarbonyl and tetrafluorobenzene units, useful for further supramolecular polarization of the chiral dyes.

\section{Introduction}

Conjugated organic compounds and polymers are employed in many technological applications and widely studied either in solution or in bulk [1]. Second harmonic generation (SHG), a nonlinear optical property which is at the foundation for advanced technologies in materials science and biological imaging, requires a fully conjugated organic structure at the molecular level and the absence of a center of symmetry in the bulk [2-6]. Centrosymmetrical molecules need stringent conditions in the self-assembly process in order to generate efficient materials for SHG $[7,8]$. On the other hand, molecular chirality offers simple design principles for push-pull and noncentrosymmetric molecules, and the nanostructuring via self-assembly of chiral organic dyes has been shown to have pronounced effects and amplifications of their SHG response [9]. Binaphthyl compounds have been exploited for the realization of second-order nonlinear optical (NLO) materials, having the combined advantages of being chromophores and carrying the required element of chirality for bulk anisotropy [10-17]. In fact, binaphthyl systems, such as that shown in Figure 1, are composed of two chromophores joined through an aryl-aryl bond, which is the element (axis) of chirality, with dihedral angles usually close to $90^{\circ}$, so that interchromophoric conjugation is not efficient. The application of the binaphthyl compounds in the field of nanosciences is recent and not yet fully explored [18-29]. In all previously reported examples of binaphthyl dyes for NLO applications, the molecular design expressing the push-pull concept was developed by placing electron donating groups in the $2,2^{\prime}$ positions and the electron accepting units in the $6,6^{\prime}$ positions (Figure 1) [10-17].

Our research group studied various compounds in which an electron donating group is conjugated through a $\pi$-bridge to an electron accepting group which is a 1,3-dicarbonyl unit able to undergo further polarization by coordination with Lewis-like metal ions [30-35]. Examples of chromophores able to undergo polarization and head to tail orientation upon the use of specific supramolecular interactions are known [36-38]. In this work, we present our synthetic approach for the obtainment of enantiopure binaphthyl systems of novel design and conception, in which the $\pi$-bridge is extended through the $3,3^{\prime}$ position. The electron deficient moieties, in the form of 1,3-dicarbonyl units for compounds 1 and iodotetrafluorobenzene units for compounds 2 , can be in principle further polarized by means of complexation with metal cations in the former case or halogen bonding acceptors (e.g., pyridines) in the latter case (Figure 2). 


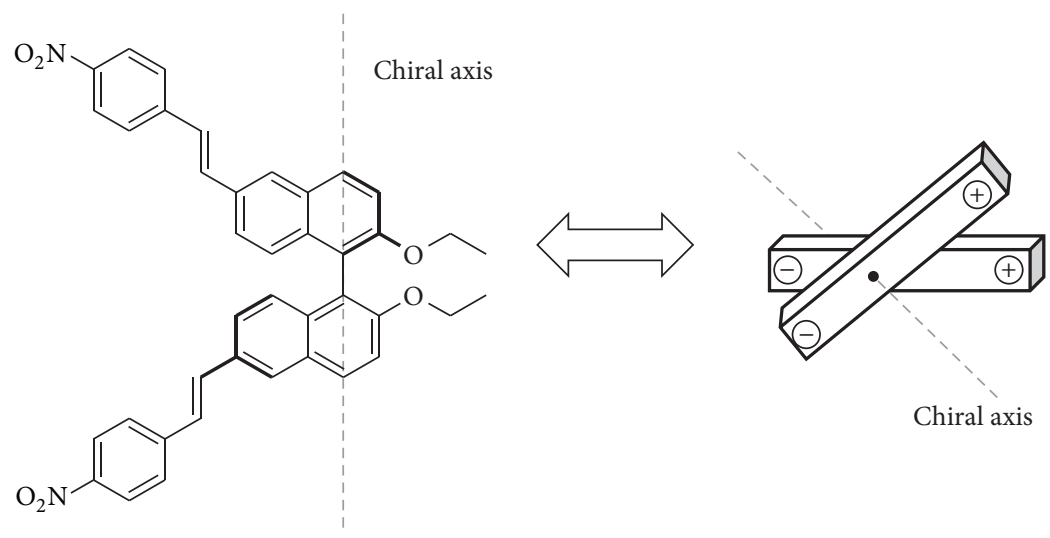

FIGURE 1: The molecular design for push-pull chiral binaphthyl derivatives [16].

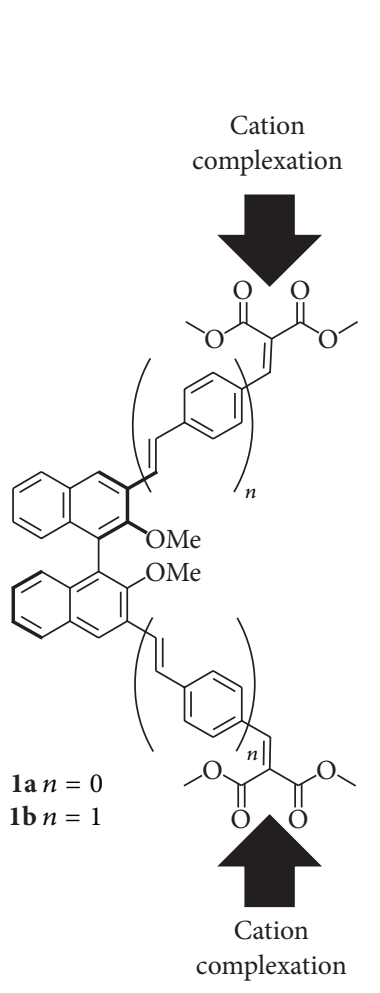

(a)

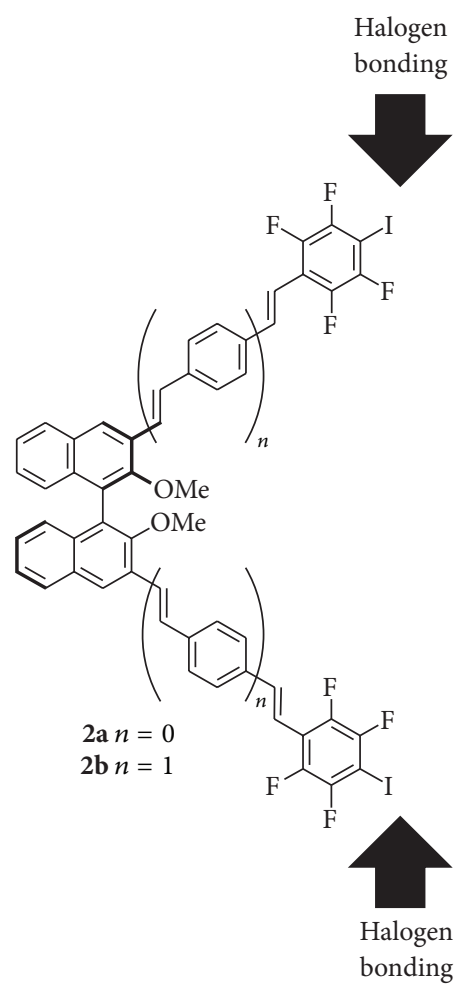

(b)

FIgURE 2: Target compounds subject of this paper.

\section{Results and Discussion}

2.1. Synthesis of the Molecular Modules. In our design strategy, the electron-donating alkoxy substituents in the $2,2^{\prime}$ positions are in an ortho relationship with respect to the growing $\pi$-bridge in the $3,3^{\prime}$ position, achieving efficient conjugation with the $\pi$-bridge. The synthesis of the key compounds is shown in Scheme 1. Enantiopure starting materials for this work were obtained via multistep syntheses starting from the commercially available enantiopure (R)-BINOL, which was chemically transformed under nonracemizing conditions.
Compound (R)-1b (Scheme 1, top) was synthesized using a Knoevenagel condensation reaction between elongated, recently reported dialdehyde (R)-3b [39] and dimethyl malonate 4 . The reaction was carried out under classical conditions (piperidine as the catalyst, continuous $\mathrm{H}_{2} \mathrm{O}$ removal with a Dean-Stark apparatus); the compound was isolated in good yield after column chromatography and fully characterized (see Appendix). On the contrary, using identical conditions, compound ( $R$ )-1a could not be obtained from dialdehyde $(R)-3 \mathbf{a}$. It is likely that the enhanced steric hindrance caused by the presence of the methoxy group ortho to the aldehyde functionality is responsible for the 
<smiles>COc1c(/C=C/c2ccc(C=O)cc2)cc2ccccc2c1-c1c(OC)c(/C=C/c2ccc(C=O)cc2)cc2ccccc12</smiles>
$3 \mathbf{b} n=1$<smiles>COC(=O)CC(=O)OC</smiles>

4

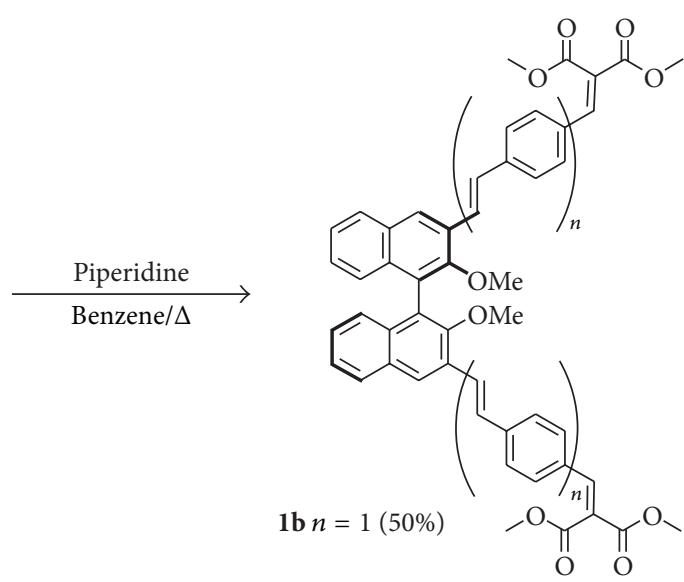

$5 \mathrm{R}=\mathrm{Br}$

$6 \mathrm{R}=\mathrm{PO}(\mathrm{OEt})_{2}$

$7 \mathrm{R}=\mathrm{P}(\mathrm{Ph})_{3}{ }^{+} \mathrm{Br}^{-}$

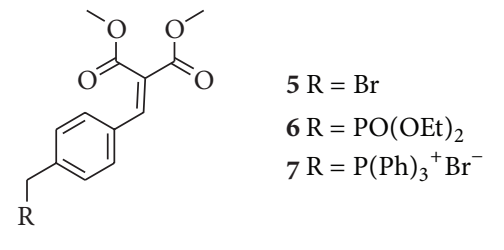

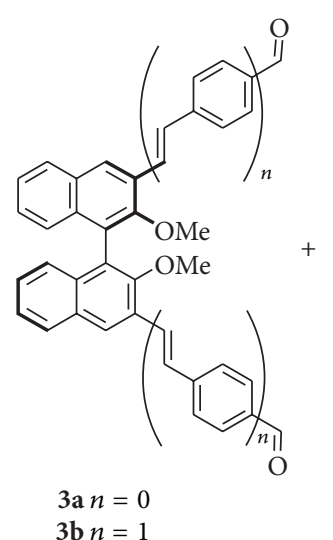

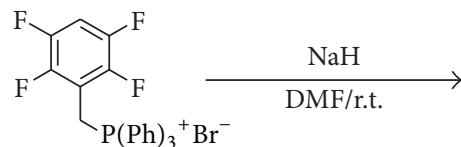

8

$9 \mathbf{b} n=1(69 \%)$<smiles>CC=Cc1c(F)c(F)cc(F)c1F</smiles>

Scheme 1: Synthesis of the molecular modules described in this paper.

reduced reactivity in this case. We also explored alternative reaction approaches to the synthesis of $(R)-\mathbf{l b}$ by means of olefination reaction (Wittig, or Horner-Wadsworth-Emmons methodologies) involving binaphthyl dialdehyde derivative $(R)$-3a in combination with $\pi$-extended phosphonate $\mathbf{6}$ or phosphonium salt 7. In both cases, however, decomposition of 6 or 7 occurred in the presence of the strong bases required for Wittig or HWE reactions, presumably because a carbon-carbon double bond, which is highly activated towards nucleophilic attack, is present in the $\pi$-extended structures.

Reaction of $(R)-\mathbf{3 a}$ and $(R)-\mathbf{3 b}$ with phosphonium salt 8 using standard Wittig conditions (NaH, DMF) afforded compounds $(R)-\mathbf{9 a}$ and $(R)-\mathbf{9 b}$ in acceptable yields. The stereochemistry of the newly carbon-carbon double bond was determined to be stereopure trans by NMR spectroscopy.
With the aim to expand the supramolecular functionalities of $\mathbf{9 b}$ we targeted the formation of halogen bonding donor sites by adding an iodine atom for each tetrafluorophenyl ring. It is known that iodine atoms, when they are covalently bound to strong electron-withdrawing groups, such as fluorinated residues, function as very efficient electron density acceptor sites [40]. The iodination reaction on the partially fluorinated rings in $\mathbf{9 b}$ was carried out at low temperature $\left(-78^{\circ} \mathrm{C}\right)$ by using $\mathrm{BuLi} / \mathrm{I}_{2}$ in dry THF under $\mathrm{N}_{2}$ atmosphere. Unfortunately the addition in para position of the iodine atom occurred partially and a mixture of the starting material $\mathbf{9 b}$ and the iodinated product $\mathbf{2 b}$ was recovered as confirmed by analysis of ${ }^{19} \mathrm{~F}-\mathrm{NMR}$ spectrum (see Figure S1 in Supplementary Material available online at http://dx.doi.org/10.1155/2015/827592). In the region of $-140 \mathrm{ppm}$ the presence of two signals, -140 and $-144 \mathrm{ppm}$, 


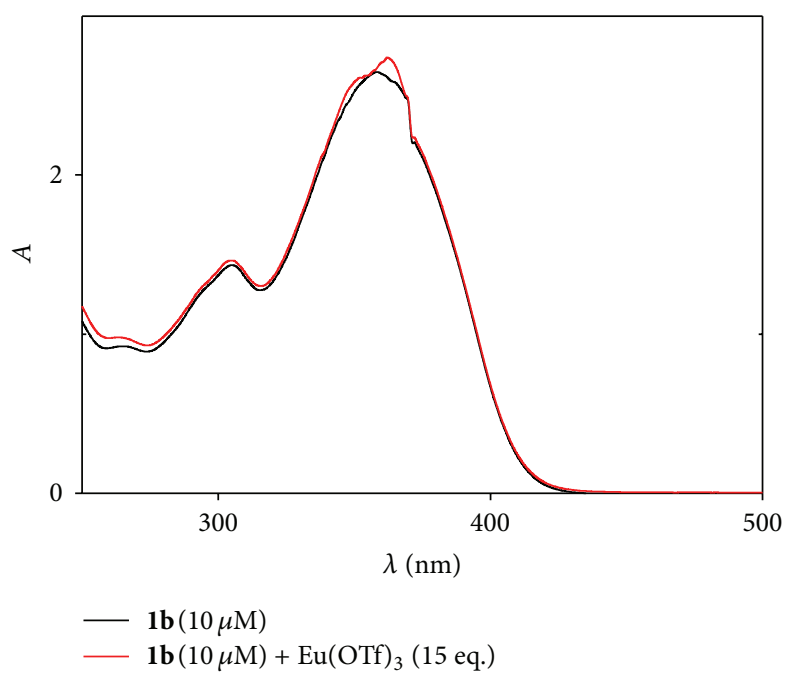

(a)

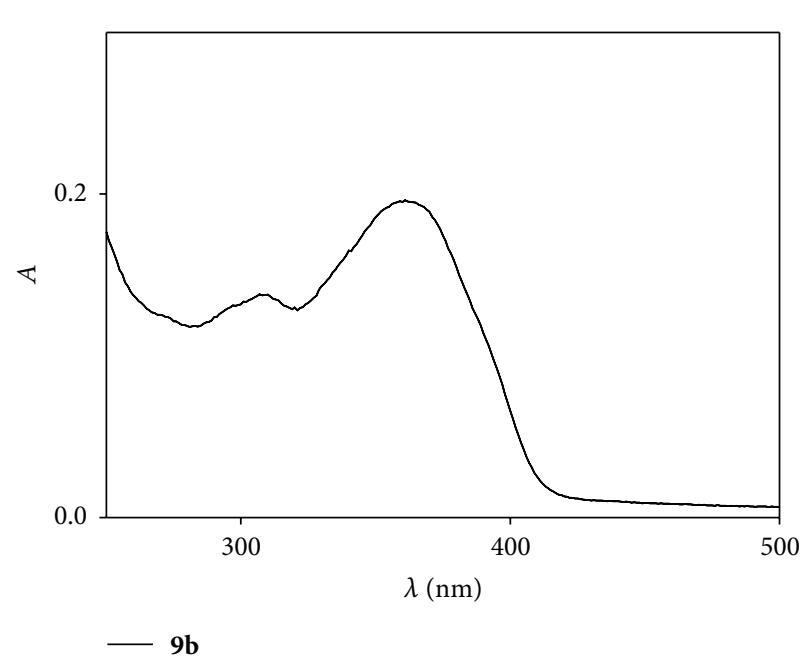

(b)

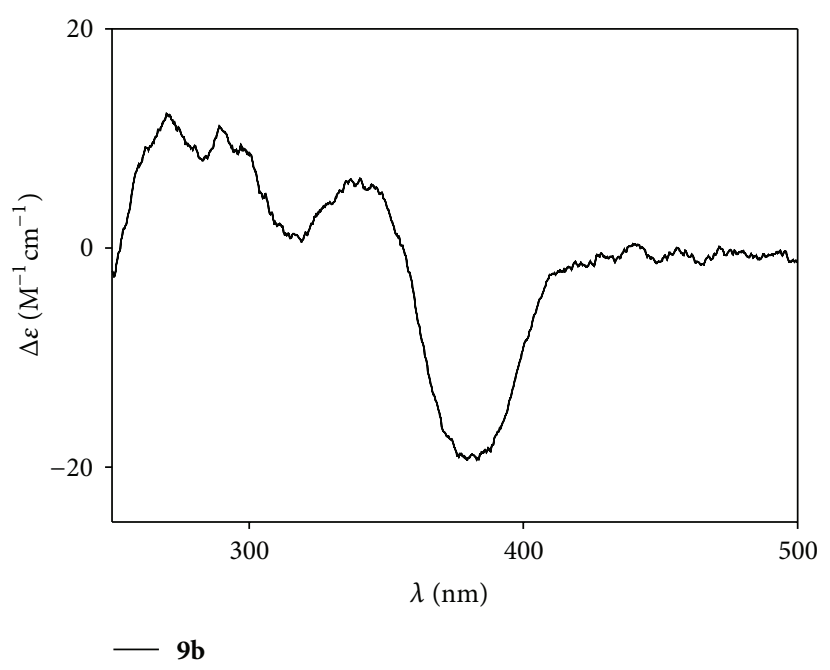

(c)

FIgURE 3: (a) Titration experiment of $\mathbf{1 b}$ with $\mathrm{Eu}(\mathrm{OTf})_{3}$ in MeCN. ((b) and (c)) UV and CD spectra of $\mathbf{9 b}(1 \mu \mathrm{M}, \mathrm{MeCN})$.

respectively, confirmed the occurrence of unreacted starting material $\mathbf{9 b}$ while the presence of the peak at $-123 \mathrm{ppm}$, characteristic for fluorine atoms on an aromatic moiety in ortho position to an iodine atom, suggested the formation of small amount of iodinated system. Other small peaks at -136 and -121 ppm which were detected in the spectrum highlighted the possible formation of different side products arising from the iodination reaction. The best ratio between hydrogenated and iodinated compound was $10: 3$. Several attempts to purify this mixture have been carried out using standard chromatography, crystallization, and cocrystallization methods; however neither a fully purification nor an enrichment in the mixture of the iodinated compound was obtained. Further attempts have been made to obtain the target halogen bonding donor compound by chaining the experimental conditions, mainly the temperature; however pure iodinated system was never isolated.
2.2. Absorption, Complexation, and Chiroptical Properties. We have recently reported on the characterization of supramolecular complexes involving push-pull chromophores in which the electron-withdrawing molecular fragment is a malonate moiety, and we have demonstrated that this moiety is able to form supramolecular, reversible complexes with metal cations (such as lanthanides) behaving as Lewis Acids [30-35]. The peculiar nature of these complexes is testified by a large red shift (ca. $100 \mathrm{~nm}$ ) of the intramolecular charge-transfer absorption band (ICT) upon complexation. In order to verify the potential of compound 1b for complexation and supramolecular polarization, we performed titrations in $\mathrm{MeCN}$ using our previously used probes $\mathrm{Eu}^{3+}$ and $\mathrm{Sc}^{3+}$, as trifluoromethanesulfonate salts, since they are readily dissolved in MeCN. As shown in Figure 3(a) the addition of up to 15 equivalents of $\mathrm{Eu}(\mathrm{OTf})_{3}$ resulted in negligible changes in the UV/Vis spectra. 
Essentially identical results were obtained with $\mathrm{Sc}(\mathrm{OTf})_{3}$. This could be caused by an inefficient complexation of the conjugated malonate moiety in $\mathbf{1 b}$ with the metal center in these conditions. In any case, since the red shift previously observed is completely lacking, the utility of 1 as supramolecularly polarizable dyes is reduced. The UV spectrum of ligand $\mathbf{l b}$ alone showed the low energy absorption band, attributable to the Intramolecular Charge Transfer band, at $358 \mathrm{~nm}$, which is similar to that obtained for 9b $(361 \mathrm{~nm})$ and to those obtained for pyridine-terminated analogous compounds [39]. The CD spectra of $\mathbf{9 b}$ showed the classical exciton couplet signature typical of binaphthyl systems, centered at $360 \mathrm{~nm}$, coincident, as expected, with the ICT $\lambda_{\max }$ of the compound.

\section{Conclusions}

We have reported the synthesis and experimental characterization of binaphthyl-based push-pull dyes of novel conception. The synthetic methodologies, building on enantiopure known binaphthyl derivatives, have been demonstrated to be viable for the construction of the $\pi$-bridge with the required stereospecificity regarding the newly formed double bond. In the case of dyes $\mathbf{1}$, a more thorough study on their inability to give the expected UV/Vis response upon interaction with the metal cation will be carried out in the near future. Regarding dyes 2 , the failure of the final iodination step suggests the possibility of the introduction of a fully functional supramolecular unit from a suitable iodinated phosphonium salt through the Wittig reaction. We are currently developing this synthetic approach.

\section{Appendix}

\section{Experimental}

General Experimental. All available compounds were purchased from commercial sources and used as received. Compounds 3a [41], 3b [39], 5 [42], and 8 [43] were prepared as previously described. THF ( $\mathrm{Na}$, benzophenone), $\mathrm{Et}_{2} \mathrm{O}\left(\mathrm{Na}\right.$, benzophenone), and $\mathrm{CH}_{2} \mathrm{Cl}_{2}\left(\mathrm{CaH}_{2}\right)$ were dried and distilled before use. Analytical thin layer chromatography was performed on silica gel, chromophore loaded, commercially available plates. Flash chromatography was carried out using silica gel (pore size $60 \AA, 230-400$ mesh). ${ }^{1} \mathrm{H}$ and ${ }^{13} \mathrm{C}$ NMR spectra were recorded from solutions in $\mathrm{CDCl}_{3}$ on $200300 \mathrm{MHz}$ or $500 \mathrm{MHz}$ spectrometer with the solvent residual proton signal or tetramethylsilane as a standard. The UV/Vis spectroscopic studies were recorded using commercially available spectrophotometers. Optical rotations were measured on a polarimeter in a $10 \mathrm{~cm}$ cell with a sodium lamp $(\lambda=589 \mathrm{~nm})$ and are reported as follows: $[\alpha]_{D}^{\text {rt }}\left(c=\mathrm{mg}(\mathrm{mL})^{-1}\right.$, solvent $)$. CD spectra were recorded at $25^{\circ} \mathrm{C}$ at a scanning speed of $50 \mathrm{~nm} \mathrm{~min}^{-1}$ and were background corrected. Each spectrum is the instrument average of four consecutive scans. Mass spectra were recorded using an electrospray ionization instrument (ESI).
General Procedure for the Titration Experiments. The titration experiments were conducted as follows: to a stock solution of the ligand (solution A) in MeCN (UV/Vis spectroscopic grade), several aliquots of the guest (solution $\mathrm{B}$ ) were added. Solution B is formed by the lanthanide triflate at higher concentration dissolved in solution $\mathrm{A}$, in order to maintain the ligand always at the same, constant concentration.

Compound 1b. A solution of $3 \mathbf{b}(58 \mathrm{mg}, 0.101 \mathrm{mmol})$, dimethyl malonate $4(43 \mathrm{mg}, 0.32 \mathrm{mmol})$, and three drops of piperidine in benzene $(5 \mathrm{~mL})$ was stirred at reflux with a Dean-Stark apparatus for $15 \mathrm{~h}$. The solvent was removed in vacuo and the reaction mixture was then treated with $\mathrm{H}_{2} \mathrm{O}(10 \mathrm{~mL})$ at room temperature, extracted with AcOEt $(3 \times 20 \mathrm{~mL})$, and dried $\left(\mathrm{Na}_{2} \mathrm{SO}_{4}\right)$. The reaction mixture was purified by flash column chromatography $\left(\mathrm{SiO}_{2}\right.$; hexane/AcOEt: $1 / 1$ to $3 / 7)$ to afford $\mathbf{l b}$ as a yellow solid $(40 \mathrm{mg}$, 50\%). MS(ESI): $m / z 825\left([M+\mathrm{Na}]^{+}, 100 \%\right), 1627([2 M+$ $\left.\mathrm{Na}]^{+}, 100 \%\right) .{ }^{1} \mathrm{H}$ NMR $\left(\mathrm{CDCl}_{3}, 300 \mathrm{MHz}, 25^{\circ} \mathrm{C}\right) \delta=8.29$ (s, $2 \mathrm{H}$; $-\mathrm{CH}=\mathrm{C}(\mathrm{COOMe})_{2}$ ), 7.97 (d, 2H; binaphthyl), 7.80 (s, $2 \mathrm{H}$; -binaphthyl), 7.74 (d, 2H; -CH-vinyl, $J=16 \mathrm{~Hz}$ ), 7.63 (d, $4 \mathrm{H}$; - ArH), 7.5-7.1 (m, 16H; -CH-binaphthyl, - $\mathrm{CH}$-vinyl and $\mathrm{ArH}$ ), 3.91 (s, 6H; -COOMe), 3.88 (s, 6H; -COOMe), 3.43 (s, $\left.6 \mathrm{H} ;-\mathrm{OCH}_{3}\right) .{ }^{13} \mathrm{C} \mathrm{NMR}\left(\mathrm{CDCl}_{3}, 75 \mathrm{MHz}, 25^{\circ} \mathrm{C}\right) \delta=167.2$ $(\mathrm{C}=\mathrm{O}), 164.5(\mathrm{C}=\mathrm{O}), 154.4(\mathrm{Cq}), 142.3(\mathrm{CH}), 140.1(\mathrm{Cq}), 133.8$ $(\mathrm{Cq}), 131.8(\mathrm{Cq}), 130.7(\mathrm{Cq}), 130.5(\mathrm{Cq}), 130.0(\mathrm{CH}), 129.3$ $(\mathrm{CH}), 128.2(\mathrm{CH}), 126.9(\mathrm{CH}), 126.5(\mathrm{CH}), 126.0(\mathrm{CH}), 125.6$ $(\mathrm{CH}), 125.2(\mathrm{CH}), 125.1(\mathrm{CH}), 124.7(\mathrm{Cq}), 61.3\left(\mathrm{CH}_{3}\right), 52.7$ $\left(\mathrm{COOCH}_{3}\right), 52.6\left(\mathrm{COOCH}_{3}\right)$.

Compound 6. A solution of $5(586 \mathrm{mg}, 1.87 \mathrm{mmol})$ and triethyl phosphite $(15.7 \mathrm{~g}, 94.3 \mathrm{mmol}, 50 \mathrm{eq})$ was refluxed in toluene $(60 \mathrm{~mL})$ for $24 \mathrm{~h}$. After cooling, the solvent and excess phosphite were removed under vacuo, and the product was purified by column chromatography (hexane/ethyl acetate $1 / 4$ to $1 / 9$ ), to yield compound 6 as a yellow oil $(559 \mathrm{mg}$, 81\%). ${ }^{1} \mathrm{H}$ NMR $\left(\mathrm{CDCl}_{3}, 300 \mathrm{MHz}, 25^{\circ} \mathrm{C}\right) \delta=7.75(\mathrm{~s}, 1 \mathrm{H}$; $\left.\operatorname{Ar}-\mathrm{C} \underline{\mathrm{H}}=\mathrm{C}(\mathrm{COOMe})_{2}\right), 7.40-7.28(\mathrm{~m}, 4 \mathrm{H} ; \mathrm{Ar} \underline{\mathrm{H}}), 4.00(\mathrm{~m}$, $\left.4 \mathrm{H} ; \mathrm{P}(\mathrm{O}) \mathrm{OCH}_{2} \mathrm{CH}_{3}\right), 3.85\left(\mathrm{~s}, 6 \mathrm{H} ;-\mathrm{COOCH}_{3}\right), 3.17(\mathrm{~d}, 2 \mathrm{H}$; $\mathrm{ArCH}_{2} \mathrm{P}(\mathrm{O}) \mathrm{OEt}$ ), 1.27 (t, $\left.6 \mathrm{H} ; \mathrm{P}(\mathrm{O}) \mathrm{OCH}_{2} \underline{\mathrm{C}}_{3}\right) .{ }^{13} \mathrm{CNMR}$ $\left(\mathrm{CDCl}_{3}, 75 \mathrm{MHz}, 25^{\circ} \mathrm{C}\right) \delta=167.1,164.4,142.3,134.7,131.2$, $130.2,129.5,125.1,62.1,52.6,34.6,32.8,16.3$.

Compound 7. A solution of $\mathrm{PPh}_{3}(295 \mathrm{mg}, 1.13 \mathrm{mmol})$ and $5(344 \mathrm{mg}, 1.10 \mathrm{mmol})$ was refluxed in toluene $(3 \mathrm{~mL})$ for $6 \mathrm{~h}$. After cooling, the precipitate was filtered off to yield compound 7 as an orange solid (310 mg, 49\%). ${ }^{1} \mathrm{H}$ NMR $\left(\mathrm{CDCl}_{3}, 300 \mathrm{MHz}, 25^{\circ} \mathrm{C}\right) \delta=7.82-7.60(\mathrm{~m}, 16 \mathrm{H} ; \mathrm{Ar} \underline{\mathrm{H}}), 7.22-$ $7.13(\mathrm{~m}, 4 \mathrm{H} ; \mathrm{Ar} \underline{\mathrm{H}}), 5.66$ (d, $\left.2 \mathrm{H} ; \mathrm{ArCH}_{2} \mathrm{PPh}_{3}\right), 3.85$ (s, 3H; $\left.-\mathrm{COOCH}_{3}\right), 3.83\left(\mathrm{~s}, 3 \mathrm{H} ;-\mathrm{COOCH}_{3}\right) .{ }^{13} \mathrm{C} \mathrm{NMR}\left(\mathrm{CDCl}_{3}\right.$, $\left.75 \mathrm{MHz}, 25^{\circ} \mathrm{C}\right) \delta=166.8,164.2,141.7,134.9,134.4,132.5,132.1$, $130.3,130.1,130.0,129.4,126.0,118.1,117.0,52.7,30.7,30.1$.

Compound 9a. NaH (5 mg, $0.2 \mathrm{mmol}$ ) was added to a solution of the phosphonium salt $8(80 \mathrm{mg}, 0.16 \mathrm{mmol})$ in dry DMF $(2 \mathrm{~mL})$. After stirring for $30 \mathrm{~min}$ at room temperature, a solution of compound $3 \mathbf{a}(27 \mathrm{mg}, 0.07 \mathrm{mmol})$ in dry DMF $(1 \mathrm{~mL})$ was added. After stirring at $40^{\circ} \mathrm{C}$ for $15 \mathrm{~h}, \mathrm{H}_{2} \mathrm{O}$ was added and the mixture was extracted with $\mathrm{CH}_{2} \mathrm{Cl}_{2}$. The 
organic phase was dried $\left(\mathrm{Na}_{2} \mathrm{SO}_{4}\right)$ and the reaction mixture purified by flash chromatography $\left(\mathrm{SiO}_{2}\right.$; hexane $\left./ \mathrm{CH}_{2} \mathrm{Cl}_{2} 7 / 3\right)$ to yield $9 \mathrm{a}$ as a white solid (10 mg, 20\%). MS(ESI): $\mathrm{m} / z 663$ $\left([M+\mathrm{H}]^{+}, 100 \%\right), 685\left([M+\mathrm{Na}]^{+}, 97 \%\right), 1347\left([2 M+\mathrm{Na}]^{+}\right.$, $40 \%) .{ }^{1} \mathrm{H}$ NMR $\left(\mathrm{CDCl}_{3}, 200 \mathrm{MHz}, 25^{\circ} \mathrm{C}\right) \delta=8.30(\mathrm{~s}, 2 \mathrm{H}$; binaphthyl), 8.03 (d, 2H; -CH-vinyl, $J=16 \mathrm{~Hz}), 8.01$ (d, 2H; binaphthyl), 7.49-7.16 (m, 10H; binaphthyl and -CH-vinyl), $6.96\left(\mathrm{~m}, 2 \mathrm{H}\right.$; - $\mathrm{CH}$ - tetrafluorophenyl), 3.45 (s, 6H; $\left.-\mathrm{OCH}_{3}\right)$.

Compound $9 \boldsymbol{b}$. $\mathrm{NaH}$ (45 mg, $1.76 \mathrm{mmol}$ ) was added to a solution of the phosphonium salt $8(593 \mathrm{mg}, 1.17 \mathrm{mmol})$ in dry DMF (2 mL). After stirring for $30 \mathrm{~min}$ at room temperature, a solution of compound $3 \mathbf{b}$ (337 $\mathrm{mg}, 0.59 \mathrm{mmol})$ in dry DMF $(3 \mathrm{~mL})$ was added. After stirring at $40^{\circ} \mathrm{C}$ for $15 \mathrm{~h}, \mathrm{H}_{2} \mathrm{O}$ was added and the mixture was extracted with $\mathrm{Et}_{2} \mathrm{O}$. The organic phase was dried $\left(\mathrm{Na}_{2} \mathrm{SO}_{4}\right)$ and the reaction mixture purified by flash chromatography $\left(\mathrm{SiO}_{2}\right.$; hexane/ $\left.\mathrm{CH}_{2} \mathrm{Cl}_{2} 7 / 3\right)$ to yield 9b as a yellow solid (350 mg, 69\%). $[\alpha]_{\mathrm{D}}^{25}=-505.6^{\circ}(\mathrm{c}=$ 0.0016, $\left.\mathrm{CH}_{2} \mathrm{Cl}_{2}\right)$. MS(ESI): $m / z 866\left([M+\mathrm{H}]^{+}, 100 \%\right) .{ }^{1} \mathrm{H}$ $\mathrm{NMR}\left(\mathrm{CDCl}_{3}, 300 \mathrm{MHz}, 25^{\circ} \mathrm{C}\right) \delta=8.30$ (s, 2H; binaphthyl), 7.96 (d, 2H; binaphthyl), 7.71-7.57 (m, 10H; -ArH- and -CHvinyl), 7.51-7.41 (m, 6H; binaphthyl and -CH-vinyl), 7.267.10 (m, 6H; binaphthyl and -CH-vinyl), 6.96 (m, 2H; -CHtetrafluorophenyl), 3.45 (s, $\left.6 \mathrm{H} ;-\mathrm{OCH}_{3}\right) .{ }^{13} \mathrm{C} \mathrm{NMR}\left(\mathrm{CDCl}_{3}\right.$, $\left.75 \mathrm{MHz}, 25^{\circ} \mathrm{C}\right) \delta=154.4(\mathrm{Cq}), 147.0(\mathrm{CF}), 144.0(\mathrm{CF}), 138.3$ $(\mathrm{Cq}), 136.9(\mathrm{Cq}), 135.9(\mathrm{Cq}), 133.7(\mathrm{Cq}), 130.8(\mathrm{Cq}), 129.8$ $(\mathrm{CH}), 128.1(\mathrm{CH}), 127.3(2 \mathrm{CH}), 127.0(2 \mathrm{CH}), 126.3(\mathrm{CH}), 126.2$ $(\mathrm{CH}), 125.6(\mathrm{CH}), 125.1(\mathrm{CH}), 124.6(\mathrm{CH}), 113.6(\mathrm{CH}), 113.0$ (Cq), $104.0(\mathrm{CH}), 103.6(\mathrm{CH}), 61.3\left(\mathrm{CH}_{3}\right)$.

\section{Conflict of Interests}

The authors declare that there is no conflict of interests regarding the publication of this paper.

\section{Acknowledgments}

Support from the University of Pavia, MIUR (Programs of National Relevant Interest PRIN Grants 2004-033354 and 2009-A5Y3N9), from CARIPLO Foundation (2007-2009) and, in part, from INSTM-Regione Lombardia (2010-2012 and 2013-2015) is gratefully acknowledged. The authors wish to thank Stefano Colombo for early experimental involvement in this work.

\section{References}

[1] A. C. Grimsdale, K. L. Chan, R. E. Martin, P. G. Jokisz, and A. B. Holmes, "Synthesis of light-emitting conjugated polymers for applications in electroluminescent devices," Chemical Reviews, vol. 109, no. 3, pp. 897-1091, 2009.

[2] S. R. Marder, "Organic nonlinear optical materials: where we have been and where we are going," Chemical Communications, no. 2, pp. 131-134, 2006.

[3] T. Verbiest, S. Sioncke, A. Persoons, L. Vyklický, and T. J. Katz, "Electric-field-modulated circular-difference effects in secondharmonic generation from a chiral liquid crystal," Angewandte Chemie International Edition, vol. 41, no. 20, pp. 3882-3884, 2002.
[4] H. Kang, A. Facchetti, H. Jiang et al., "Ultralarge hyperpolarizability twisted $\pi$-electron system electro-optic chromophores: synthesis, solid-state and solution-phase structural characteristics, electronic structures, linear and nonlinear optical properties, and computational studies," Journal of the American Chemical Society, vol. 129, no. 11, pp. 3267-3286, 2007.

[5] P. A. Sullivan and L. R. Dalton, "Theory-inspired development of organic electro-optic materials," Accounts of Chemical Research, vol. 43, no. 1, pp. 10-18, 2010.

[6] U. Gubler and C. Bosshard, "A new twist for nonlinear optics," Nature Materials, vol. 1, no. 4, pp. 209-210, 2002.

[7] G. J. Ashwell, "Centrosymmetric molecules for second harmonic generation," Advanced Materials, vol. 8, no. 3, pp. 248250, 1996.

[8] F. Würthner, J. Schmidt, M. Stolte, and R. Wortmann, "Hydrogen-bond-directed head-to-tail orientation of dipolar merocyanine dyes: a strategy for the design of electrooptical materials," Angewandte Chemie International Edition, vol. 45, no. 23, pp. 3842-3846, 2006.

[9] T. Verbiest, S. van Elshocht, M. Kauranen et al., "Strong enhancement of nonlinear optical properties through supramolecular chirality," Science, vol. 282, no. 5390, pp. 913-915, 1998.

[10] M. Caricato, A. K. Sharma, C. Coluccini, and D. Pasini, "Nanostructuring with chirality: binaphthyl-based synthons for the production of functional oriented nanomaterials," Nanoscale, vol. 6, no. 13, pp. 7165-7174, 2014.

[11] G. Yang, Y. Si, and Z. Su, "Chiroptical, linear, and second-order nonlinear optical properties of binaphthol derivatives," Organic and Biomolecular Chemistry, vol. 10, no. 42, pp. 8418-8425, 2012.

[12] D. Cornelis, E. Franz, I. Asselberghs, K. Clays, T. Verbiest, and G. Koeckelberghs, "Interchromophoric interactions in chiral $\mathrm{X}$-type $\pi$-conjugated oligomers: a linear and nonlinear optical study," Journal of the American Chemical Society, vol. 133, no. 5, pp. 1317-1327, 2011.

[13] G. Koekcelberghs, T. Verbiest, M. Vangheluwe et al., "Influence of monomer optical purity on the conformation and properties of chiral, donor-embedded polybinaphthalenes for nonlinear optical purposes," Chemistry of Materials, vol. 17, no. 1, pp. 118121, 2005.

[14] G. Koeckelberghs, M. Vangheluwe, I. Picard et al., "Synthesis and properties of new chiral donor-embedded polybinaphthalenes for nonlinear optical applications," Macromolecules, vol. 37, no. 23, pp. 8530-8537, 2004.

[15] B. J. Coe, E. C. Harper, K. Clays, and E. Franz, "The synthesis of chiral, cationic nonlinear optical dyes based on the 1,1/binaphthalenyl unit," Dyes and Pigments, vol. 87, no. 1, pp. 22-29, 2010.

[16] H.-J. Deussen, C. Boutton, N. Thorup et al., "New chiral bis(dipolar) 6,6' -disubstituted binaphthol derivatives for second-order nonlinear optics," Chemistry - A European Journal, vol. 4, no. 2, pp. 240-250, 1998.

[17] H.-J. Deussen, E. Hendrickx, C. Boutton et al., "Novel chiral bisdipolar 6,6'-disubstituted binaphthol derivatives for secondorder nonlinear optics: synthesis and linear and nonlinear optical properties," Journal of the American Chemical Society, vol. 118 , no. 29 , pp. 6841-6852, 1996.

[18] A. Bencini, C. Coluccini, A. Garau et al., "A BINOL-based chiral polyammonium receptor for highly enantioselective recognition and fluorescence sensing of $(S, S)$-tartaric acid in aqueous solution," Chemical Communications, vol. 48, no. 84, pp. 1042810430, 2012. 
[19] M. Caricato, A. Delforge, D. Bonifazi, D. Dondi, A. Mazzanti, and D. Pasini, "Chiral nanostructuring of multivalent macrocycles in solution and on surfaces," Organic \& Biomolecular Chemistry, 2015.

[20] A. Saad, O. Jeannin, and M. Fourmigué, "A binaphtholsubstituted tetrathiafulvalene with axial chirality and its enantiopure TCNQF4 charge-transfer salts," New Journal of Chemistry, vol. 35, no. 5, pp. 1004-1010, 2011.

[21] S. Colombo, C. Coluccini, M. Caricato, C. Gargiulli, G. Gattuso, and D. Pasini, "Shape selectivity in the synthesis of chiral macrocyclic amides," Tetrahedron, vol. 66, no. 23, pp. 42064211, 2010.

[22] C. Coluccini, A. Mazzanti, and D. Pasini, "Locked chromophores as CD and NMR probes for the helical conformation of tetraamidic macrocycles," Organic \& Biomolecular Chemistry, vol. 8, no. 8, pp. 1807-1815, 2010.

[23] S. Y.-L. Leung, W. H. Lam, and V. W.-W. Yam, "Dynamic scaffold of chiral binaphthol derivatives with the alkynylplatinum(II) terpyridine moiety," Proceedings of the National Academy of Sciences of the United States of America, vol. 110, no. 20, pp. 7986-7991, 2013.

[24] A. Shockravi, A. Javadi, and E. Abouzari-Lotf, "Binaphthylbased macromolecules: a review," RSC Advances, vol. 3, no. 19, pp. 6717-6746, 2013.

[25] M. Caricato, N. J. Leza, K. Roy et al., "A chiroptical probe for sensing metal ions in water," European Journal of Organic Chemistry, no. 27, pp. 6078-6083, 2013.

[26] M. Caricato, A. Olmo, C. Gargiulli, G. Gattuso, and D. Pasini, "A 'clicked' macrocyclic probe incorporating Binol as the signalling unit for the chiroptical sensing of anions," Tetrahedron, vol. 68, no. 38, pp. 7861-7866, 2012.

[27] M. Caricato, C. Coluccini, D. Dondi, D. A. V. Griend, and D. Pasini, "Nesting complexation of $\mathrm{C}_{60}$ with large, rigid $D_{2}$ symmetrical macrocycles," Organic \& Biomolecular Chemistry, vol. 8, no. 14, pp. 3272-3280, 2010.

[28] C. Coluccini, D. Dondi, M. Caricato, A. Taglietti, M. Boiocchi, and D. Pasini, "Structurally-variable, rigid and optically-active $\mathrm{D}_{2}$ and $\mathrm{D}_{3}$ macrocycles possessing recognition properties towards $\mathrm{C}_{60}$," Organic and Biomolecular Chemistry, vol. 8, no. 7, pp. 1640-1649, 2010.

[29] A. Moletti, C. Coluccini, D. Pasini, and A. Taglietti, "A chiral probe for the detection of $\mathrm{Cu}$ (ii) by $\mathrm{UV}, \mathrm{CD}$ and emission spectroscopies," Dalton Transactions, no. 16, pp. 1588-1592, 2007.

[30] C. Coluccini, A. K. Sharma, M. Caricato et al., "Switching of emissive and NLO properties in push-pull chromophores with crescent PPV-like structures," Physical Chemistry Chemical Physics, vol. 15, no. 5, pp. 1666-1674, 2013.

[31] C. Coluccini, A. K. Sharma, D. Merli, D. V. Griend, B. Mannucci, and D. Pasini, "Spectroscopic and electrochemical sensing of lanthanides with $\pi$-extended chromophores incorporating ferrocenes and a coordinative end," Dalton Transactions, vol. 40, no. 44, pp. 11719-11725, 2011.

[32] M. Caricato, C. Coluccini, D. A. V. Griend, A. Forni, and D. Pasini, "From red to blue shift: switching the binding affinity from the acceptor to the donor end by increasing the $\pi$-bridge in push-pull chromophores with coordinative ends," New Journal of Chemistry, vol. 37, no. 9, pp. 2792-2799, 2013.

[33] D. Pasini, P. P. Righetti, and V. Rossi, "Malonate crown ethers as building blocks for novel D- $\pi$-A chromophores," Organic Letters, vol. 4, no. 1, pp. 23-26, 2002.
[34] L. Garlaschelli, I. Messina, D. Pasini, and P. P. Righetti, "Fullerene ylidene malonate supramolecular triads," European Journal of Organic Chemistry, no. 20, pp. 3385-3392, 2002.

[35] C. Coluccini, P. Metrangolo, M. Parachini, D. Pasini, G. Resnati, and P. Righetti, "Push-pull' supramolecular chromophores supported on cyclopolymers," Journal of Polymer Science Part A: Polymer Chemistry, vol. 46, no. 15, pp. 5202-5213, 2008.

[36] J. M. Klopp, D. Pasini, J. D. Byers, C. Grant Willson, and J. M. J. Fréchet, "Microlithographic assessment of a novel family of transparent and etch-resistant chemically amplified $193 \mathrm{~nm}$ resists based on cyclopolymers," Chemistry of Materials, vol. 13, no. 11, pp. 4147-4153, 2001.

[37] A. Facchetti, E. Annoni, L. Beverina et al., "Very large electrooptic responses in $\mathrm{H}$-bonded heteroaromatic films grown by physical vapour deposition," Nature Materials, vol. 3, no. 12, pp. 910-917, 2004.

[38] E. Cariati, A. Forni, S. Biella et al., "Tuning second-order NLO responses through halogen bonding," Chemical Communications, no. 25, pp. 2590-2592, 2007.

[39] C. Coluccini, M. Caricato, E. Cariati, A. Forni, and D. Pasini, "Synthesis, chiroptical and SHG properties of polarizable pushpull dyes built on $\pi$-extended binaphthyls," RSC Advances, vol. 5, no. 28, pp. 21495-21503, 2015.

[40] P. Metrangolo, F. Meyer, T. Pilati, G. Resnati, and G. Terraneo, "Halogen bonding in supramolecular chemistry," Angewandte Chemie-International Edition, vol. 47, no. 33, pp. 6114-6127, 2008.

[41] H. T. Stock and R. M. Kellogg, "Synthesis of enantiomerically pure thiocrown ethers derived from $1,1^{\prime}$-binaphthalene-2, $2^{\prime}$ diol," The Journal of Organic Chemistry, vol. 61, no. 9, pp. 30933105, 1996.

[42] C. Almansa, L. A. Gómez, F. L. Cavalcanti et al., "Diphenylpropionic acids as new AT1 selective angiotensin II antagonists," Journal of Medicinal Chemistry, vol. 39, no. 11, pp. 2197-2206, 1996.

[43] E. Cariati, G. Cavallo, A. Forni et al., "Self-complementary nonlinear optical-phores targeted to halogen bond-driven selfassembly of electro-optic materials," Crystal Growth \& Design, vol. 11, no. 12, pp. 5642-5648, 2011. 

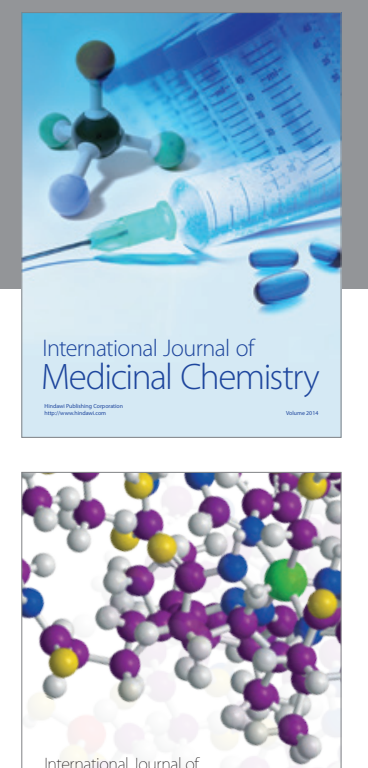

\section{Carbohydrate} Chemistry

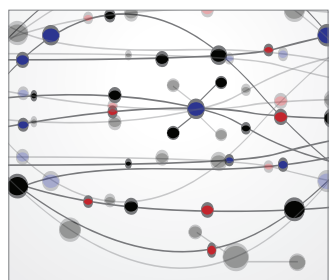

The Scientific World Journal
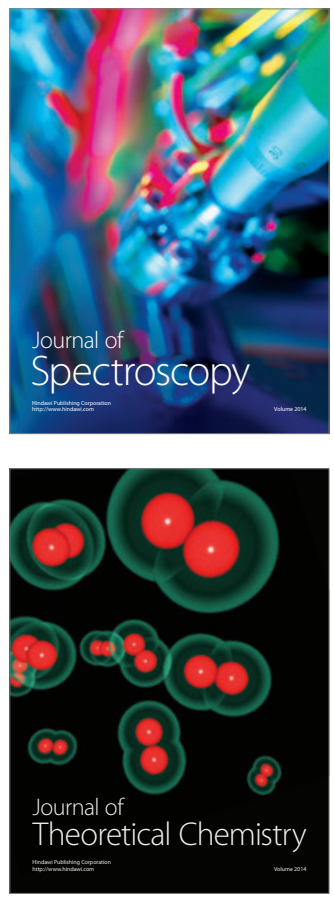
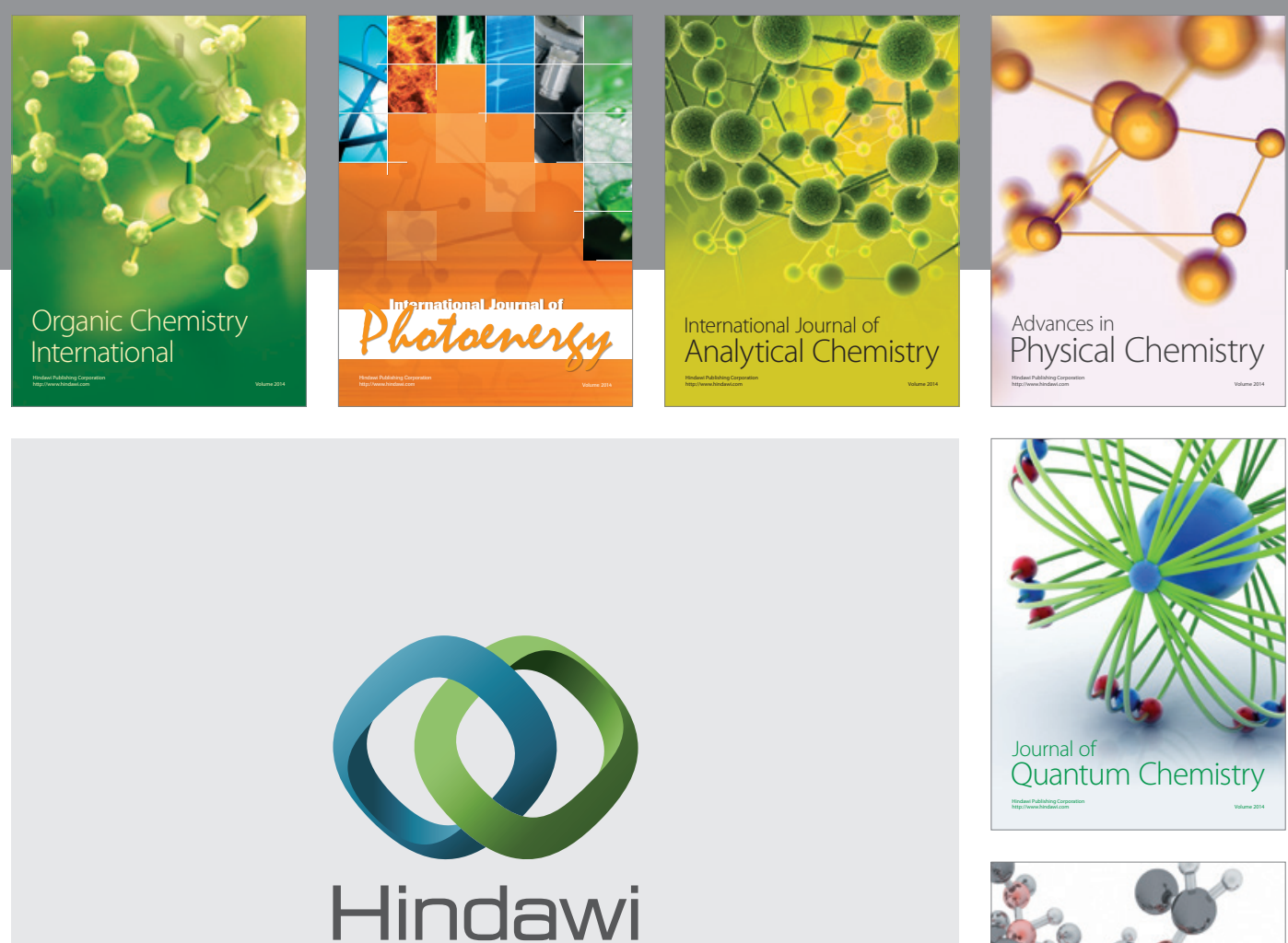

Submit your manuscripts at

http://www.hindawi.com

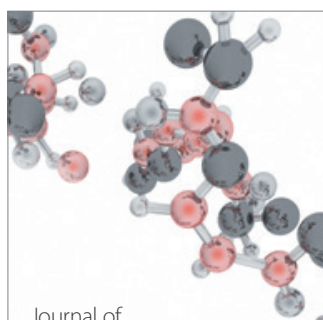

Analytical Methods

in Chemistry

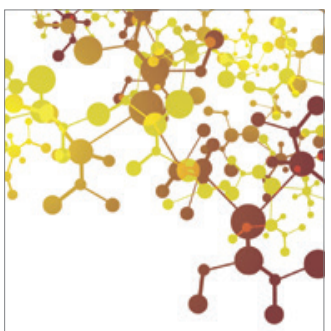

Journal of

Applied Chemistry

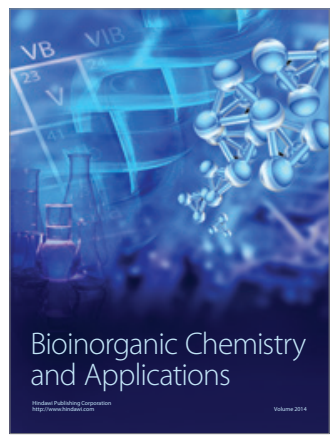

Inorganic Chemistry
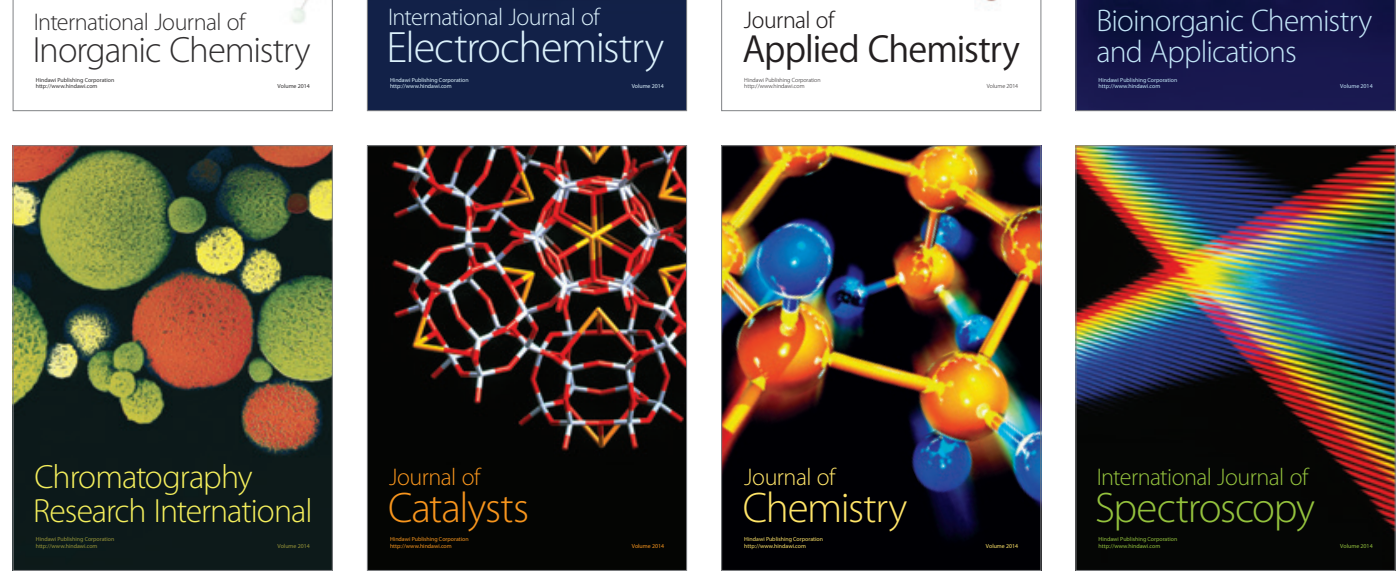